

\title{
Association between $F$ TO polymorphism in exon 3 with carcass and meat quality traits in crossbred ducks
}

\author{
W. Gan, Q. Song, N.N. Zhang, X.P. Xiong, D.M.C. Wang and L. Li \\ Farm Animal Genetic Resources Exploration and Innovation Key Laboratory \\ of Sichuan Province, Sichuan Agricultural University, Ya'an, Sichuan, China \\ Corresponding author: L. Li \\ E-mail: liliang@sicau.edu.cn \\ Genet. Mol. Res. 14 (2): 6699-6714 (2015) \\ Received August 12, 2014 \\ Accepted January 19, 2015 \\ Published June 18, 2015 \\ DOI http://dx.doi.org/10.4238/2015.June.18.14
}

\begin{abstract}
The fat mass and obesity-associated gene (FTO) is an excellent candidate gene that affects energy metabolism. Single nucleotide polymorphisms (SNPs) in FTO are associated with carcass and meat quality traits in pigs, cattle, and rabbits. The aim of this study was to investigate the association between novel SNPs in the FTO coding region and carcass and meat quality traits in 95 crossbred ducks, using DNA sequencing. We found two transitions G/A (SNP 387 and 473) within exon 3. SNP 387 was a synonymous mutation, whereas SNP 473 was a missense mutation. Association analysis suggested that SNP g.387G $>$ A was significantly associated with all of the carcass traits measured, the intramuscular fat content (IMF), cooking yield $(\mathrm{CY}), \mathrm{pH}$ values $45 \mathrm{~min}$ after slaughter $(\mathrm{pH} 45 \mathrm{~m})$, drip losses from the breast muscle, and the leg muscle $(\mathrm{P}<0.05)$. For SNP g.473G $>$ A, the genotype AA exhibited greater leg muscle weight than the genotypes $\mathrm{GG}$ or AG $(\mathrm{P}<0.05)$. The $\mathrm{D}$ value suggested that the two SNPs exhibited strong linkage disequilibrium. Three haplotypes $\left(\mathrm{G}_{1} \mathrm{G}_{2}, \mathrm{G}_{1} \mathrm{~A}_{2}\right.$, and $A_{1} A_{2}$ ) were significantly associated with IMF, CY, the a* value, and all of the carcass traits measured $(\mathrm{P}<0.05)$. The results suggest
\end{abstract}


that FTO is a candidate locus that affects carcass and meat quality traits in ducks.

Key words: Crossbred duck; Fat mass and obesity-associated gene; Carcass and meat quality trait; Single nucleotide polymorphism

\section{INTRODUCTION}

Carcass and meat quality traits are important in animal breeding programs, and include live weight (LW), carcass weight $(\mathrm{CW}), \mathrm{pH}$, semi-eviscerated weight (SEW), eviscerated weight (EW), meat color (MC), drip loss (DL), tenderness, intramuscular fat (IMF) content, and other traits. However, these traits have low heritabilities (Boukha et al., 2011) and are difficult to improve using traditional artificial selection. Moreover, their measurement is both expensive and difficult, and can only be conducted after death. Because of advances in molecular genetics technology, genomic selection strategies and marker-assisted selection programs have been used, and are considered to be the most effective selection approaches for low-heritability traits since they are easily measured (Gao et al., 2007). Furthermore, the identification of gene polymorphisms that are associated with production traits, and linkage analysis, are important and commonly used tools to characterize candidate genes at the DNA level.

Several factors, such as genes, the breed studied, the rearing system, sex, and age could influence carcass and meat quality traits (Santos et al., 2007; Galián et al., 2008; Tůmová et al., 2014). Fat content is a crucial aspect of animal meat quality, and the aim in modern animal breeding is to reduce fat deposits and increase lean growth. DNA markers in several obesity-related genes have been associated with fat deposition and carcass and meat quality traits in different animal populations. For example, the leptin gene, which is also called the obese gene, codes for a circulating protein that regulates dietary intake by binding to leptin receptors (Prokop et al., 2012). Polymorphisms in the leptin gene have been identified, and association analyses have shown that this gene might be an important source of variability in carcass and meat quality traits between different cattle populations (Li et al., 2013; Tian et al., 2013). Therefore, it is important to investigate the association between obesity-related genes and carcass and meat quality traits for duck breeding programs.

The fat mass and obesity-associated gene (FTO) was originally cloned in mice (Peters et al., 1999), and energy expenditure is increased in FTO-deficient mice (Fischer et al., 2009). FTO transcript expression has been detected in all of the tissues tested, and is the highest in the brain (McTaggart et al., 2011; Xing et al., 2013), which plays an important role in regulating feed intake and energy expenditure, commensurate with perceived whole-body energy requirements (Richards and Proszkowiec-Weglarz, 2007). In humans, several single nucleotide polymorphisms (SNPs) of FTO that are associated with the body mass index (BMI) have been found, which contribute to obesity and related diseases (Hubacek et al., 2010; Binh et al., 2013). Jia et al. (2012) reported that in chickens, FTO is related to glucose metabolism, body weight (BW), and fat content. In pigs, FTO mRNA expression increases with increasing $\mathrm{BW}$, and is significantly associated with IMF (Tao et al., 2013). In Italian Duroc pigs, an FTO mutation is significantly associated with obesity-related traits (back fat thickness, visible intermuscular fat, and lean cuts) $(\mathrm{P}<0.01)$ (Fontanesi et al., 2010). SNP g. 167T $>\mathrm{G}$ in the 5 ' flanking region of the pig FTO is associated with backfat thickness, abdominal fat weight, and lean meat content in Polish Landrace (Szydlowski et al., 2012). A novel SNP (C1071T) has been 
detected in exon 5 of $F T O$ using polymerase chain reaction single-strand conformation polymorphism (PCR-SSCP) analysis, and DNA sequencing, in five Chinese indigenous cattle breeds, which exhibit significant differences between genotypes (CC,TT, and CT) in backfat thickness and longissimus muscle area (Wei et al., 2011). Fan et al. (2009) found that SNPs c.46-139A >T in intron 1 are significantly associated $(\mathrm{P}<0.01)$ with average daily gain $(\mathrm{ADG})$ and the total muscle lipid content. These studies have revealed that $F T O$ is important in fatty acid metabolism.

Based on these observations, FTO could be considered an important candidate gene for fat deposition traits, and may affect carcass and meat quality traits. However, no study has yet attempted to detect variation in FTO in ducks. Therefore, the objectives of the present study were to estimate allele and genotype frequencies in FTO polymorphisms, and to determine the effects of FTO polymorphisms on carcass and meat quality traits in crossbred ducks.

\section{MATERIAL AND METHODS}

\section{Animals}

The study was conducted using $95 \mathrm{~F}_{2}$ offspring of Cherry Valley ducks $\mathrm{x}$ Liancheng white ducks. All of the ducks were reared under the same conditions in the Experimental Farm for Poultry Breeding of the Sichuan Agricultural University, and were slaughtered at 14 weeks old. All of the experimental procedures were approved by the Institutional Animal Care and Use Committee of Sichuan Agricultural University.

\section{Samples collection and phenotypic data}

Blood samples ( $1 \mathrm{~mL})$ were collected before slaughter to analyze SNPs in exon 3 of FTO. The breast muscle (BM) and leg muscle (LM) were divided into five pieces to evaluate meat quality traits.

The carcass traits included LW, CW, SEW, EW, breast muscle weight (BMW), and leg muscle weight (LMW). CW was measured after the removal of feathers. The SEW was measured after removal of the trachea, esophagus, gastrointestinal tract, spleen, pancreas, and gonads. The EW was measured after the removal of the head, claws, heart, liver, gizzard, glandular stomach, and abdominal fat.

Details of the sample collection and meat quality trait measurements are provided in (Lee et al., 2010, 2012). The IMF was measured using Soxhlet petroleum-ether extraction, and $\mathrm{pH}$ values were measured using a $\mathrm{pH}-\mathrm{Star}$ (RMatthaus, Klausa,Germany) at 45 $\min \left(\mathrm{pH}_{45 \min }\right)$ and $24 \mathrm{~h}\left(\mathrm{pH}_{24 \mathrm{~h}}\right)$ after slaughter. MC parameters (L*, lightness; $\mathrm{a}^{*}$, redness; and $\mathrm{b}^{*}$, yellowness) were measured using a photoelectric spectrocolorimeter (CR-300, Minolta Camera Co., Japan). To determine the cooking yield (CY), a cube of muscle was taken from the BM and the LM, weighed, placed in a bag, and incubated in water bath at $100^{\circ} \mathrm{C}$ for $30 \mathrm{~min}$ to reach a central internal temperature of $71^{\circ} \mathrm{C}$. The bag was then cooled at room temperature for $30 \mathrm{~min}$ and the solid portion was re-weighed. DL were scored based on size-standardized samples that were weighed, suspended in a plastic bag (ensuring that the samples had not been in contact with the bag) at $4^{\circ} \mathrm{C}$ for $24 \mathrm{~h}$, removed from the bag, gently blotted dry, and weighed. IMF, CY, and DL were all expressed as a percentage of the initial sample weight. In order to minimize error, the same person was assigned to measure the same trait. 


\section{Total DNA extraction and primer design}

Genomic DNA was extracted from the blood samples using the phenol/chloroform method following standard procedures (Clements et al., 2008), and stored at $-20^{\circ} \mathrm{C}$ for PCR amplifications. All of the RNA samples obtained were qualitatively and quantitatively assessed by $1.5 \%$ agarose gel electrophoresis, and their OD 260/280 ratio was evaluated. The concentration of total DNA was determined spectrophotometrically.

Primers were designed according to duck exon 3 of the FTO sequence (NW_004676795.1) from GenBank, for the amplification of a 759-bp product. The 759-bp fragment included exon 3 and parts of introns 2 and 3 . The sense and antisense primers were 5'-TACCTCCCATTACTCACC-3' and 5'-TATCCCTGTCCATTCCT-3', respectively. The primers were synthesized by GENEWIZ Inc. (Suzhou, China).

\section{PCR amplifications}

The PCR consisted of 2 X $12.5 \mu \mathrm{L}$ Taq PCR Master-Mix ( 2 X PCR buffer, $0.4 \mathrm{mM}$ of each dNTP, $3 \mathrm{mM} \mathrm{MgCl}$, and $0.1 \mathrm{U} / \mu \mathrm{L}$ Taq DNA polymerase), $1 \mu \mathrm{L}$ of primer ( $10 \mu \mathrm{M}$ of each of the sense and antisense primers), $9.5 \mu \mathrm{LddH}_{2} \mathrm{O}$, and $1 \mu \mathrm{L}$ genomic DNA template, in a $25-\mu \mathrm{L}$ final reaction volume. The PCR was performed under the following conditions: one denaturation cycle at $95^{\circ} \mathrm{C}$ for $5 \mathrm{~min}$, followed by 36 cycles at $95^{\circ} \mathrm{C}$ for $30 \mathrm{~s}, 48.1^{\circ} \mathrm{C}$ for $30 \mathrm{~s}$, and $72^{\circ} \mathrm{C}$ for $1 \mathrm{~min}$, and an extension cycle at $72^{\circ} \mathrm{C}$ for $10 \mathrm{~min}$. The PCR products were used for direct sequencing by GENEWIZ Inc. The same primer pairs as listed above were used for the sequencing.

\section{Sequence analysis}

Polymorphic sites were detected by sequence comparisons using the DNAMAN software (http://dnaman.software.informer.com/). The duck FTO mRNA sequence (XM_005017005.1) was used for confirming the exact location of the two SNPs, and for identifying the mutation type. $\mathrm{D}^{\prime}$ (deviation ratio to reveal the degree of deviation) and $\mathrm{r}^{2}$ (the coefficient of linkage disequilibrium) were evaluated using Haploview 4.2 (http://haploview.software.informer. com/4.2/). If there was no linkage disequilibrium between the two SNPs, then:

$$
\mathrm{f}(\mathrm{G} 1 \mathrm{G} 2)=\mathrm{f}_{\mathrm{G} 1} \mathrm{f}_{\mathrm{G} 2} \quad \text { (Equation 1) }
$$

If alleles at the two loci were not randomly associated, then there would be a deviation (D) in the expected frequencies. The $\mathrm{D}, \mathrm{D}^{\prime}$, and $\mathrm{r}^{2}$ were evaluated by the following:

$$
\begin{gathered}
\mathrm{D}=\mathrm{f}\left(\mathrm{G}_{\mathrm{G} 1 \mathrm{G} 2}\right)-\mathrm{f}_{\mathrm{G} 1} \mathrm{f}_{\mathrm{G} 2} \\
\mathrm{D}^{\prime}=\mathrm{D} / \min \left(\mathrm{f}_{\mathrm{G} 1} \mathrm{f}_{\mathrm{G} 2}, \mathrm{f}_{\mathrm{a} 1} \mathrm{f}_{\mathrm{a} 2}\right)
\end{gathered}
$$




$$
\mathrm{r}^{2}=\mathrm{D} / \mathrm{f}_{\mathrm{G} 1} \mathrm{f}_{\mathrm{G} 2} \mathrm{f}_{\mathrm{a} 1} \mathrm{f}_{\mathrm{a} 2}
$$

(Equation 4)

$\mathrm{F}_{\mathrm{G} 1}$ and $\mathrm{f}_{\mathrm{a} 1}$ represent the frequency of $\mathrm{G}$ and $\mathrm{A}$, respectively, in SNP g.387G $>\mathrm{A}$, and $\mathrm{f}_{\mathrm{G} 2}$ and $\mathrm{f}_{\mathrm{a} 2}$ represent the frequency of $\mathrm{G}$ and $\mathrm{A}$, respectively, in SNP g.473G $>$ A.

\section{Statistical analysis}

The genotype and allele frequencies were assessed, and the Hardy-Weinberg equilibrium of the SNPs was analyzed, by the $\chi^{2}$ test using the SPSS software. Association analyses were performed using the Least Significant Difference method with General Linear Models $(\mathrm{GLMs})$ in SAS 8.0, and significant differences $(\mathrm{P}<0.05)$ are presented as means \pm standard errors (SE). Analyses were conducted for each SNP separately. The linear model used was:

$$
\mathrm{Y}_{\mathrm{ikm}}=\mu+\mathrm{C}_{\mathrm{i}}+\mathrm{G}_{\mathrm{k}}+\mathrm{S}_{\mathrm{m}}+\mathrm{E}_{\mathrm{ikm}} \quad \text { (Equation 5) }
$$

where $Y_{i k l m}$ is the observation for the trait, $\mu$ is the overall population mean, $C_{i}$ is the effect of the crossbreed combination $(I=1,2,3), G_{k}$ is the effect of genotype ( $k=G G, G A$, or AA), $S_{m}$ is a fixed effect that is associated with sex $\left(\mathrm{m}=\right.$ male or female), and $\mathrm{E}_{\mathrm{ikm}}$ is the random error.

\section{RESULTS}

\section{Identification of SNPs and genotyping}

The PCR products were 759-bp long (which was consistent with the target fragment), had good specificity, and could be directly sequenced. Exon 3 was identified by BLAST. By comparing them with FTO mRNA sequences, two SNPs were located, called g. $387 \mathrm{G}>\mathrm{A}$ and g.473G $>$ A. Both SNPs were genotyped for three genotypes: GG, AA, and AG (Figure 1). After studying the protein sequence, we found that SNP 387 was a synonymous mutation (GTA/GT $\underline{\text { G }}$ both code $\left.{ }^{129} \mathrm{His}\right)$, whereas SNP 473 was a non-synonymous mutation (A $\underline{G G} / \mathrm{A} \underline{A G}$ code ${ }^{158} \mathrm{Ser} /{ }^{158} \mathrm{Phe}$, respectively). Phe is an essential amino acid in humans; therefore, the g. $473 \mathrm{G}>\mathrm{A}$ SNP should be further studied to clarify its expression and the effects of this mutation.

\section{Genotype frequency and population genetic indices}

The genotype frequency of AA $(0.178)$ at site g.387G $>$ A was lower than those of genotypes AG (0.411) and GG (0.411); the frequency of alleles $\mathrm{G}$ and $\mathrm{A}$ were 0.615 and 0.385 , respectively (Table 1). The frequency of genotype GG for site g.473G $>$ A was 0.757 , and that of genotype AG (0.211) was higher than that of genotype AA (0.032). The frequency of alleles $\mathrm{G}$ and $\mathrm{A}$ were 0.865 and 0.135 , respectively. The $\chi^{2}$ test showed that the population was not at Hardy-Weinberg equilibrium for the polymorphisms at the sites detected. 


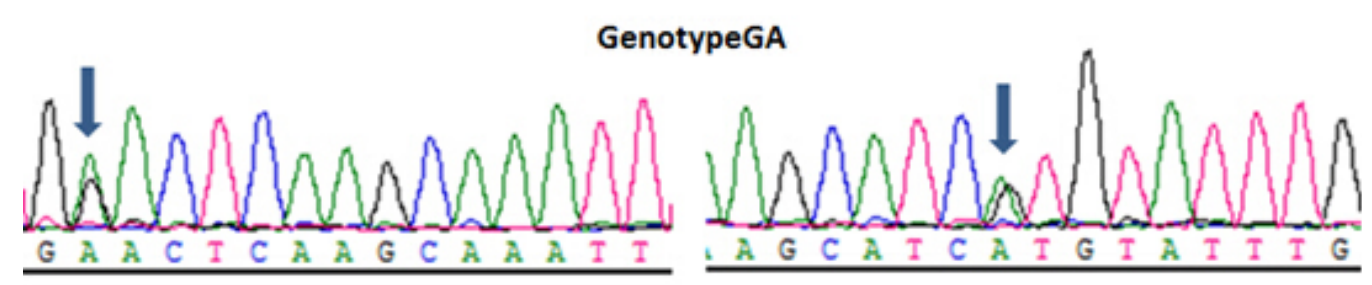

GenotypeGG
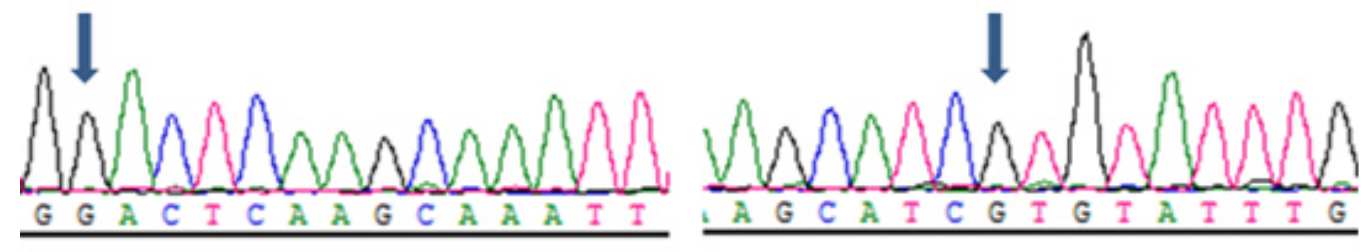

GenotypeAA
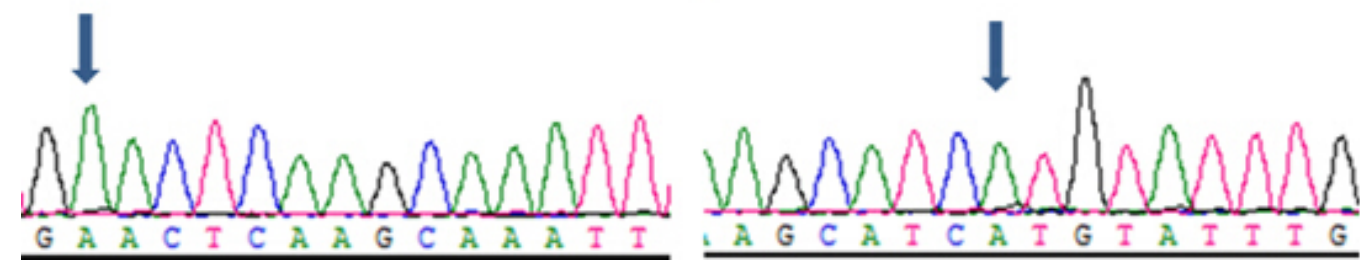

Figure 1. Identification of SNPs and genotyping.

\begin{tabular}{|c|c|c|c|c|c|c|}
\hline \multirow{2}{*}{ Sequence variant } & \multicolumn{3}{|c|}{ Genotype frequency } & \multicolumn{2}{|c|}{ Allele frequency } & \multirow[t]{2}{*}{$\chi^{2}$} \\
\hline & GG & AA & $\mathrm{AG}$ & G & A & \\
\hline g. $387 \mathrm{G}>A$ & $0.411(39)$ & $0.178(17)$ & $0.411(39)$ & 0.615 & 0.385 & $13.23^{*}$ \\
\hline g. $473 \mathrm{G}>\mathrm{A}$ & $0.757(72)$ & $0.032(3)$ & $0.211(20)$ & 0.865 & 0.135 & $132.07^{* *}$ \\
\hline
\end{tabular}

$\chi^{2}$ (HWE), Hardy-Weinberg equilibrium using the $\chi^{2}$ test; ${ }^{*}$ significant difference at the $\mathrm{P}<0.01$ level; *significant difference at the $\mathrm{P}<0.05$ level.

\section{Haplotype analysis}

Three different haplotypes were identified (g.387G $>$ A was the first, followed by g. $473 \mathrm{G}>\mathrm{A}$ ) in the duck population: $\mathrm{G}_{1} \mathrm{G}_{2}, \mathrm{G}_{1} \mathrm{~A}_{2}$ and $\mathrm{A}_{1} \mathrm{~A}_{2}$ (Table 2). The frequencies of the three haplotypes were $0.463,0.305$, and 0.232 , respectively. 
Table 2. Different haplotypes of FTO in exon 3 in ducks.

\begin{tabular}{lcccc}
\hline Haplotype & Number & Frequency & $\mathrm{D}^{\prime}$ & $\mathrm{r}^{2}$ \\
\hline $\mathrm{G}_{1} \mathrm{G}_{2}$ & 44 & 0.463 & 0.831 & 0.172 \\
$\mathrm{~A}_{1} \mathrm{G}_{2}$ & 29 & 0.305 & & \\
$\mathrm{~A}_{1} \mathrm{~A}_{2}$ & 22 & 0.232 & & \\
\hline
\end{tabular}

\section{Association between SNPs in exon 3 of FTO and carcass traits}

In the present study, FTO g. $387 \mathrm{G}>$ A SNP was significantly associated with all of the carcass traits considered (Table 3). The AA genotype exhibited the highest values for the carcass traits, which were significantly higher than the GG genotype for LW, CW, SEW, EW, and were significantly higher than the GG and GA genotypes for BMW $(\mathrm{P}<0.05)$. Therefore, the AA genotype may be positively associated with carcass traits. As with $\mathrm{g} .387 \mathrm{G}>\mathrm{A}$, the AA genotype exhibited the highest carcass trait values in g.473G $>$ A SNP, but was only significantly associated with LMW.

\section{Association between SNPs in exon 3 of FTO and meat quality traits}

The results of the association analysis of SNP g. $387 \mathrm{G}>$ A are presented in Table 4. There was a significant association between the FTO polymorphisms and IMF, CY, $\mathrm{pH}_{45 \min }$, and $\mathrm{DL}$ in the $\mathrm{BM}$, and IMF and $\mathrm{DL}$ in the $\mathrm{LM}(\mathrm{P}<0.05)$. In the $\mathrm{BM}$, animals with the AA genotype had higher values of IMF, CY, and $\mathrm{pH}_{45 \mathrm{~m}}$ than those with the GG genotype $(\mathrm{P}<0.05)$, which had a lower DL $(\mathrm{P}<0.05)$ than those with the GA genotype. Dominance effects for the DL were significant $(\mathrm{P}<0.05)$. In the LM, GG-genotype ducks exhibited a DL of 4.392, which was significantly higher than that of ducks with the AA genotype (3.092; P $<0.05)$. Genotype AA had a significantly higher IMF (12.306) than the genotype GG (9.923) $(\mathrm{P}<0.05)$.

Meat quality traits were compared between the genotypes in g.473G $>$ A (Table 5). No significant associations were found between $\mathrm{g} .473 \mathrm{G}>\mathrm{A}$ and any of the meat quality traits $(\mathrm{P}>$ $0.05)$, but additive effects for $\mathrm{CY}$ and $\mathrm{pH}_{45 \min }$ in the $\mathrm{BM}$ and $\mathrm{LM}$ were significant $(\mathrm{P}<0.05)$.

\section{Association between different haplotypes and carcass and meat quality traits}

The GLM showed that the haplotypes had a significant effect on all of the carcass traits (Table 6). Furthermore, the analysis showed that the $A_{1} A_{2}$ haplotype had the highest values for all of the carcass traits, which were significantly higher than those of the $G_{1} G_{2}$ haplotype for $\mathrm{LW}, \mathrm{CW}, \mathrm{SEW}, \mathrm{EW}$, and $\mathrm{BMW}(\mathrm{P}<0.05)$. The $\mathrm{A}_{1} \mathrm{~A}_{2}$ and $\mathrm{A}_{1} \mathrm{G}_{2}$ haplotypes had significantly higher $L M W$ values than the $\mathrm{G}_{1} \mathrm{G}_{2}$ haplotype $(P<0.05)$.

There were significant associations between the different haplotypes and the different carcass traits (Table 7). Animals with the $\mathrm{A}_{1} \mathrm{~A}_{2}$ haplotype had higher IMF and $\mathrm{CL}$ values in the $B M$ than those with the $G_{1} G_{2}$ haplotype $(P<0.05)$. For the $L M$, haplotype $A_{1} A_{2}$ had a higher IMF than haplotype $G_{1} G_{2}(P<0.05)$, but its a* value was significantly lower than that of haplotype $\mathrm{G}_{1} \mathrm{G}_{2}(\mathrm{P}<0.05)$. 


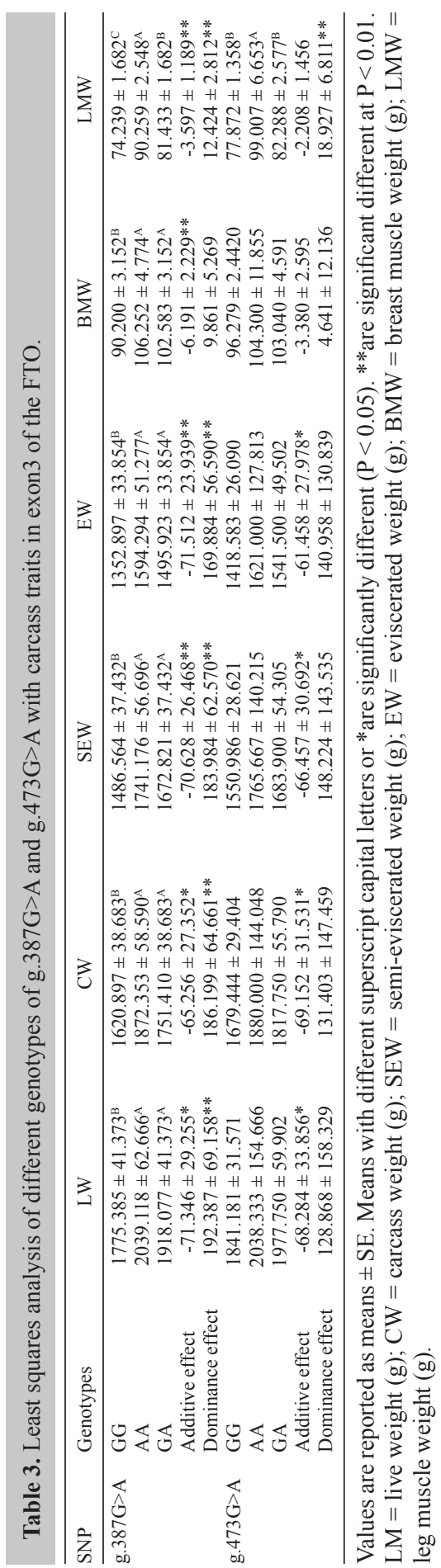




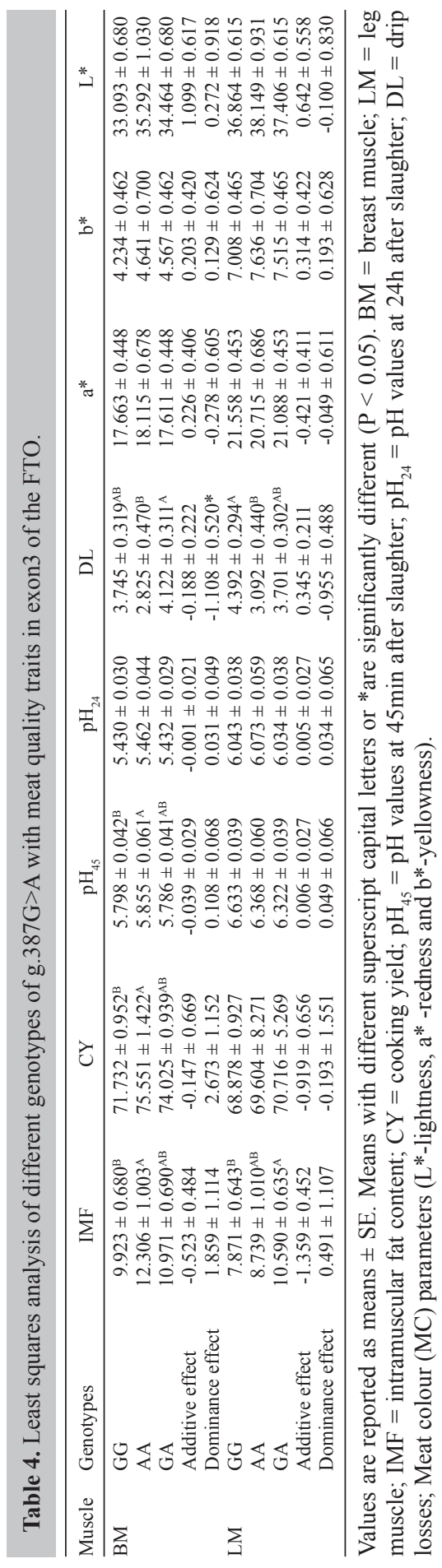




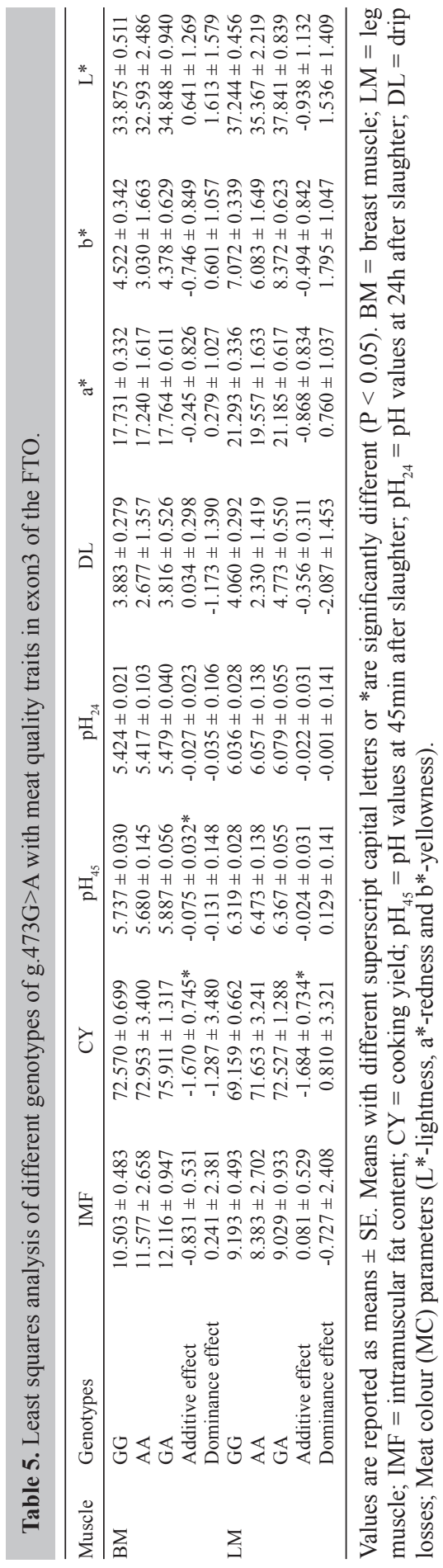







W. Gan et al.

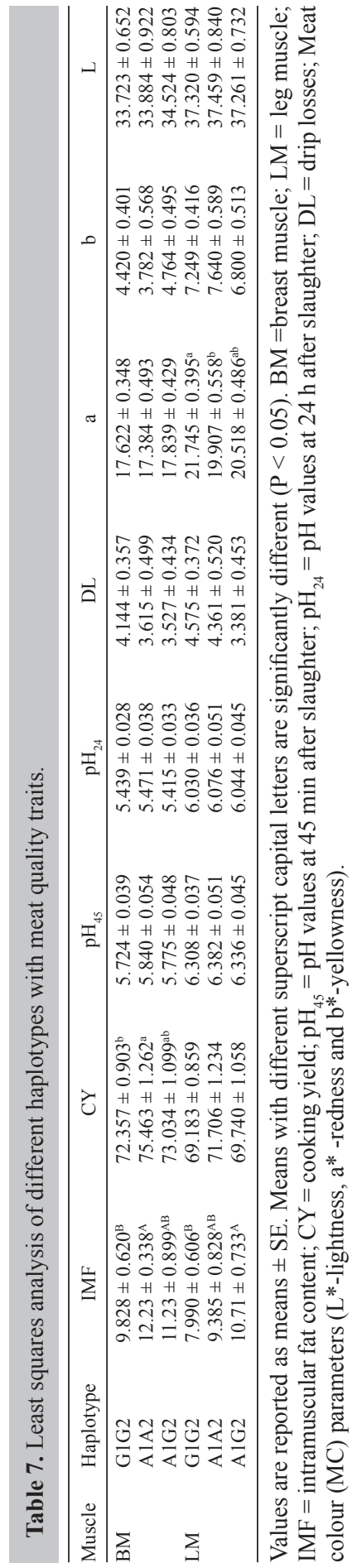




\section{DISCUSSION}

As a transcriptional coactivator (Wu et al., 2010), FTO has been identified as an obesity-related gene (Gerken et al., 2007). Wang et al. (2012) reported that the hypothalamus and cerebellum exhibit relatively high $F T O$ mRNA expression levels in male leghorn layers. By sequencing $2.0 \mathrm{~kb}$ of the $5^{\prime}$ flanking region of porcine FTO, the SNP g.1191A $>$ T has been detected, and was significantly associated with the IMF content in a Jinhua $x$ Pietrain $\mathrm{F}_{2}$ reference population $(\mathrm{P}<0.05)$ (Zhang et al., 2009). The results of these studies indicate that FTO variants are associated with fatness traits in breeds selected for a low fat content, and can be used as important candidate genes for molecular markers of carcass and meat quality traits.

The several FTO SNPs that have been detected are significantly associated with production performance. In commercial pig populations, allele C of the $F T O \mathrm{SNP}$ g. $400 \mathrm{C}>\mathrm{G}$ in exon 3 is significantly associated with backfat depth, and allele $G$ is significantly associated with muscle traits and has the greatest effect on thoracic tissues (Dvořáková et al., 2012). The FTO SNPs c.499G $>$ A and c. $453 \mathrm{C}>\mathrm{A}$ in exon 3 are significantly associated with $\mathrm{BW}$ at 35,70 , and 84 days of age in New Zealand rabbits $(\mathrm{P}<0.01)$, and the synonymous SNP c.660T $>\mathrm{C}$ is significantly associated with $\mathrm{BW}$ at 84 days of age, ADG, and the IMF content of the longissimus lumborum in Ira rabbits $(\mathrm{P}<0.01)$ (Zhang et al., 2013). Fontanesi et al. (2009) found that the FTO SNP g.276T $>\mathrm{G}$ in intron 4 is associated with IMF deposition in Italian Duroc pigs, and the feed: gain ratio in Italian Large White pigs. The FTO SNP c.594C $>\mathrm{G}$ in exon 3 is significantly associated with the ADG and the muscle total lipid content in ISU Berkshire $\mathrm{x}$ Yorkshire pigs $(\mathrm{P}<0.01)$. In addition, FTO polymorphisms are associated with $\mathrm{BW}$ and ADG, as well as hot carcass weight $(\mathrm{HCW})$, in crossbred beef cattle $(\mathrm{P}<0.05)$ (Rempel et al., 2012), LW at slaughter, CW, and lean weight in paternal half-sib families of Slovenian Simmental cattle (Jevšinek Skok et al., 2011). Our study showed that FTO polymorphisms in exon 3 had significant effects on carcass and meat quality traits. To the best of our knowledge, this is the first study that has demonstrated an association between FTO coding regions and carcass and meat quality traits in ducks. It is also important to determine whether FTO plays a role in the development of other traits in ducks (such as growth traits).

All of the ducks studied deviated from the Hardy-Weinberg equilibrium for the two SNPs sites $(\mathrm{P}<0.05)$, which may indicate that artificial selection has been more important than natural selection at these gene sites. The three haplotypes that were found to support the results of a previous study by Lee et al. (2012), which also reported strong linkage disequilibrium (Zhao et al., 2013). Analysis at the protein level has revealed that the substitution of serine by a phenylalanine in SNP 473 would not affect its secondary and tertiary structures, confirming the lack of a significant association with meat quality traits. Carcass and meat quality could be affected by LW (Galián et al., 2009; Choi et al., 2013), which is what we found in SNP 387. The AA genotype of SNP 387 did not differ significantly from the GA genotype for most of the traits, indicating a dominant effect of the A allele.

Joo et al. (2013) showed that the quality of fresh meat can be controlled by the manipulation of muscle fiber characteristics, and that the IMF content is positively correlated with the amount of red muscle fiber but is negatively correlated with the amount of white muscle fiber. It should be noted that there were differences between the BM and LM results, which may indicate that muscle fiber characteristics are also a crucial aspect of duck meat quality. Estimated aerobic capacity data have suggested that the BM and LM are mainly composed of fast and slow muscle fibers, respectively, in poultry (Turner and Butler, 1988). Meat tenderness, 
IMF, and cooking loss could be affected by the degradation of cytoskeletal proteins in chickens, which is slower in the LM than the BM (Tomaszewska-Gras et al., 2011). In embryonic stages of the Peking duck, the development of the BM always lags behind that of the LM (Li et al., 2010). Tang et al (2013) reported that the level of myostatin mRNA expression in the LM is higher than that in the BM at 70 days of age in the Wanxi White goose. Therefore, the different effects of FTO polymorphisms on meat quality (Tables 4 and 5) between the BM and the LM could be associated with their different physiological characteristic and anatomical positions.

In contrast to previous reports, the synonymous mutation g. $387 \mathrm{G}>\mathrm{A}$ was significantly associated with carcass and meat quality traits; however, there was no significant association between the missense mutation SNP g.473G $>$ A and meat quality traits. It is important to understand the mechanism of action of these polymorphisms on the traits in question, particularly those that do not cause amino acid changes but that may be linked to other, as yet unknown, causative mutations. Based on the significant association we found between SNP g.387G $>$ A of FTO and carcass and meat quality traits, we suggest that FTO may be an important candidate gene that affects carcass and meat quality traits in ducks.

\section{ACKNOWLEDGMENTS}

Research supported by the Innovative Research Team of Sichuan Province of China (\#2011JTD0032) and the Science and Technology Support Program of Sichuan Province (\#2011NZ00908).

\section{REFERENCES}

Binh TQ, Phuong PT, Nhung BT, Thoang DD, et al. (2013). Association of the common FTO-rs9939609 polymorphism with type 2 diabetes, independent of obesity-related traits in a Vietnamese population. Gene 513: 31-35.

Boukha A, Bonfatti V, Cecchinato A, Albera A, et al. (2011). Genetic parameters of carcass and meat quality traits of double muscled Piedmontese cattle. Meat Sci. 89: 84-90.

Choi YM, Nam KW, Choe JH, Ryu YC, et al. (2013). Growth, carcass, fiber type, and meat quality characteristics in Large White pigs with different live weights. Livest. Sci. 155: 123-129.

Clements DN, Wood S, Carter SD and Ollier WE (2008). Assessment of the quality and quantity of genomic DNA recovered from canine blood samples by three different extraction methods. Res. Vet. Sci. 85: 74-79.

Dvořáková V, Bartenschlager H, Stratil A, Horák P, et al. (2012). Association between polymorphism in the FTO gene and growth and carcass traits in pig crosses. Genet. Sel. Evol. 44: 1-8.

Fan B, Du ZQ and Rothschild MF (2009). The fat mass and obesity-associated (FTO) gene is associated with intramuscular fat content and growth rate in the pig. Anim. Biotechnol. 20: 58-70.

Fischer J, Koch L, Emmerling C, Vierkotten J, et al. (2009). Inactivation of the Fto gene protects from obesity. Nature 458: 894-898.

Fontanesi L, Scotti E, Buttazzoni L, Davoli R, et al. (2009). The porcine fat mass and obesity associated (FTO) gene is associated with fat deposition in Italian Duroc pigs. Anim. Genet. 40: 90-93.

Fontanesi L, Scotti E, Buttazzoni L, Dall'Olio S, et al. (2010). Confirmed association between a single nucleotide polymorphism in the FTO gene and obesity-related traits in heavy pigs. Mol. Biol. Rep. 37: 461-466.

Galián M, Poto Á, Santaella M and Peinado B (2008). Effects of the rearing system on the quality traits of the carcass, meat and fat of the Chato Murciano pig. Anim. Sci. J. 79: 487-497.

Galián M, Poto A and Peinado B (2009). Carcass and meat quality traits of the Chato Murciano pig slaughtered at different weights. Livest. Sci. 124: 314-320.

Gao Y, Zhang R, Hu X and Li N (2007). Application of genomic technologies to the improvement of meat quality of farm animals. Meat Sci. 77: 36-45.

Gerken T, Girard CA, Tung YL, Webby C J, et al. (2007). The obesity-associated FTO gene encodes a 2-oxoglutaratedependent nucleic acid demethylase. Science 318: 1469-1472.

Hubacek JA, Stanek V, Gebauerová M, Pilipcincová A, et al. (2010). A FTO variant and risk of acute coronary syndrome.

Genetics and Molecular Research 14 (2): 6699-6714 (2015)

CFUNPEC-RP www.funpecrp.com.br 
Clin. Chim. Acta 411: 1069.

Jevšinek Skok D, Kunej T, Renčelj A, Razpet A, et al. (2011). Use of SNP markers within the fat mass and obesityassociated (FTO) gene to verify pedigrees and determine haplotypes in paternal half-sib families of Slovenian Simmental cattle. Agr. Conspec. Sci. 76: 333-336.

Jia X, Nie Q, Lamont SJ and Zhang X (2012). Variation in sequence and expression of the avian FTO, and association with glucose metabolism, body weight, fatness and body composition in chickens. Int. J. Obesity 36: 1054-1061.

Joo ST, Kim GD, Hwang YH and Ryu YC (2013). Control of fresh meat quality through manipulation of muscle fiber characteristics. Meat Sci. 95: 828-836.

Lee E, Kim J, Lim K, Ryu Y, et al. (2012). Effects of variation in porcine MYOD1 gene on muscle fiber characteristics, lean meat production, and meat quality traits. Meat Sci. 92: 36-43.

Lee SH, Choi YM, Choe JH, Kim JM, et al. (2010). Association between polymorphisms of the heart fatty acid binding protein gene and intramuscular fat content, fatty acid composition, and meat quality in Berkshire breed. Meat Sci. 86: 794-800.

Li L, Liu HH, Xu F, Si JM, et al. (2010). MyoD expression profile and developmental differences of leg and breast muscle in Peking duck (Anas platyrhynchos Domestica) during embryonic to neonatal stages. Micron 41: 847-852.

Li X, Ekerljung M, Lundstrom K and Lunden A (2013). Association of polymorphisms at DGAT1, leptin, SCD1, CAPN1 and CAST genes with color, marbling and water holding capacity in meat from beef cattle populations in Sweden. Meat Sci. 94: 153-158.

McTaggart JS, Lee S, Iberl M, Church C, et al. (2011). FTO is expressed in neurones throughout the brain and its expression is unaltered by fasting. PloS One 6: e27968.

Peters T, Ausmeier K and Rüther U (1999). Cloning of Fatso (Fto), a novel gene deleted by the Fused toes (Ft) mouse mutation. Mamm. Genome 10: 983-986.

Prokop JW, Duff RJ, Ball HC, Copeland DL, et al. (2012). Leptin and leptin receptor: analysis of a structure to function relationship in interaction and evolution from humans to fish. Peptides 38: 326-36.

Rempel LA, Casas Eduardo, Shackelford SD and Wheeler TL (2012). Relationship of polymorphisms within metabolic genes and carcass traits in crossbred beef cattle. J. Anim. Sci. 90: 1311-1316.

Richards MP and Proszkowiec-Weglarz M (2007). Mechanisms regulating feed intake, energy expenditure, and body weight in poultry. Poultry Sci. 86: 1478-1490.

Santos VA, Silva SR, Mena EG and Azevedo JM (2007). Live weight and sex effects on carcass and meat quality of "Borrego terrincho-PDO" suckling lambs. Meat Sci. 77: 654-661.

Szydlowski M, Salamon S, Grzes M and Switonski M (2012). SNP in the 5' flanking region of the pig FTO gene is associated with fatness in Polish Landrace. Livest. Sci. 150: 397-400.

Tang Q, Song C, Zhang S, Hu Y, et al. (2013). Gene expression profile of IGF1 and MSTN mRNA and their correlation with carcass traits in different breeds of geese at $70 \mathrm{~d}$ of age. Br. Poult. Sci. 55: 76-80.

Tao X, Men XM, Deng B and Xu ZW (2013). Effects of breed, postnatal development, and nutrition on mRNA expression of the FTO gene in porcine muscle and its relationship with intramuscular fat deposition. Czech J. Anim. Sci. 58: 381-388.

Tian J, Zhao Z, Zhang L, Zhang Q, et al. (2013). Association of the leptin gene E2-169T >C and E3-299T >A mutations with carcass and meat quality traits of the Chinese Simmental-cross steers. Gene 518: 443-448.

Tomaszewska-Gras J, Schreurs FJG and Kijowski J (2011). Post mortem development of meat quality as related to changes in cytoskeletal proteins of chicken muscles. Br. Poult. Sci. 52: 189-201.

Tůmová E, Bízková Z, Skřivanová V, Chodová D, et al. (2014). Comparisons of carcass and meat quality among rabbit breeds of different sizes, and hybrid rabbits. Livest. Sci. 165: 8-14.

Turner DL and Butler PJ (1988). The aerobic capacity of locomotory muscles in the tufted duck, Aythya fuligula. J. Exp. Biol. 135: 445-460.

Wang YF, Rao KQ, Yuan LX, Everaert N, et al. (2012). Chicken FTO gene: tissue-specific expression, brain distribution, breed difference and effect of fasting. Comp. Biochem. Phys. A 163: 246-252.

Wei SJ, Zan LS, Ujan JA, Wang HB, et al. (2011). Novel polymorphism of the bovine fat mass and obesity-associated (FTO) gene are related to backfat thickness and longissimus muscle area in five Chinese native cattle breeds. Afr. J. Biotechnol. 10: 2820-2824.

Wu Q, Saunders RA, Szkudlarek-mikho M, La Serna ID, et al. (2010). The obesity-associated Fto gene is a transcriptional coactivator. Biochem. Bioph. Res. Co. 401: 390-395.

Xing JY, Jing WQ and Jiang YL (2013). Molecular characterization and expression analysis of fat mass and obesityassociated gene in rabbit. J. Genet. 92: 481-488.

Zhang GW, Gao L, Chen SY, Zhao XB, et al. (2013). Single nucleotide polymorphisms in the FTO gene and their association with growth and meat quality traits in rabbits. Gene 527: 553-557.

Zhang LF, Miao XT, Hua XC, Jiang XL, et al. (2009). Polymorphism in 5 ' regulatory region of the porcine fat mass and obesity associated (FTO) gene is associated with intramuscular fat content in a Jinhua X Pietrain F2 reference 
population. J. Anim. Vet. Adv. 8: 2329-2334.

Zhao YF, Rong EG, Wang SZ, Zhang H, et al. (2013). Identification of SNPs of the L-BABP and L-FABP and their association with growth and body composition traits in chicken. Poultry Sci. 50: 300-310. 